\title{
Effect of Cisplatin on Cerebellar Cortex of Albino Rat and Possible Protective Role of Granulocyte Colony Stimulating Factor versus Citrullus Lanatus Juice: A Histological Study
}

Original Article

\author{
${ }^{1}$ Abeer F. Abdel Mohsen, ${ }^{1}$ Nagwa A. Ahmed, ${ }^{2}$ Zainab M. Altaib and \\ ${ }^{2}$ Shaimaa M. Zaher
}

Histology Department, Faculty of Medicine, ${ }^{1}$ Cairo University, ${ }^{2}$ Helwan University, Egypt

\begin{abstract}
Background: Cisplatin has a major antitumor effect against a broad range of solid tumors. Yet, its clinical use is limited by its harmful effects especially on the nervous system.

Aim of the Work: Assessment of the effect of cisplatin on histological structure of cerebellar cortex and the possible protective role of granulocyte colony stimulating factor (G-CSF) versus citrullus lanatus juice.

Materials and Methods: Forty adult male albino rats were assigned to a group of four: Control group, group I: received cisplatin $(10 \mathrm{mg} / \mathrm{kg})$ on the 6th and 13th days of the study via intraperitoneal (IP) injection, group II: received G-CSF (50 $\mu \mathrm{g} / \mathrm{kg}$ ) for five consecutive days via subcutaneous injection then received as group I, group III: received cisplatin as group I as well as citrullus lanatus juice ( $4 \mathrm{ml} / \mathrm{kg}$ ) daily for 16 days via oral gavage. Blood samples were taken to measure plasma malondialdehyde (MDA) and reduced glutathione (GSH) levels. Cerebellar biopsies were processed for light microscopy using H\&E and immunohistochemical stains (glial fibrillary acidic protein (GFAP) \& caspase-3) as well as for electron microscopy. Morphometric and statistical studies were done for number of Purkinje cells, thickness of granular layer, area percent of GFAP positive cells and optical density of caspase-3 positive cells.

Results: Group I showed significantly high MDA and significantly low GSH levels, shrinkage, distortion, deep staining of disarranged Purkinje cells with nuclear pyknosis, swollen mitochondria with destroyed cristae and dilated Golgi apparatus. Separated granule cells were shrunken with dark irregular nuclei. Results were confirmed by morphometric and statistical studies. These changes were ameliorated in both group II and III with great extent in group II than in group III.

Conclusion: G-CSF could improve cisplatin induced cerebellar cortical changes better than citrullus lanatus juice.
\end{abstract}

Received: 05 December 2019, Accepted: 13 December 2019

Key Words: Cerebellum; cisplatin; citrullus lanatus juice; granulocyte colony stimulating factor; neurotoxicity.

Corresponding Author: Shaimaa M. Zaher, MSc, Histology Department, Faculty of Medicine, Helwan University, Egypt, Tel.: +20 1096958323, E-mail: shaimaazaher6884@gmail.com

ISSN: $1110-0559$, Vol. 43, No.3

\section{INTRODUCTION}

Cisplatin is one of the best and first metal-based chemotherapeutic medication, utilized for treatment of many malignancies like malignant tumors of the testis, ovaries, bladder, lungs, stomach, head and neck ${ }^{[1]}$. It exerts its anticancer activity by binding with genomic and mitochondrial deoxyribonucleic acid (DNA). This action creates DNA lesions, arrests its replication, production of messenger ribonucleic acid (mRNA) and proteins. In addition, it activates many transduction pathways which in turn induce cell necrosis or apoptosis ${ }^{[2]}$. The usage of cisplatin for chemotherapeutic purposes is hindered by its numerous side effects which include nephrotoxicity, ototoxicity, and neurotoxicity ${ }^{[3]}$.

Granulocyte colony stimulating factor (G-CSF) is a glycoprotein that binds to a single homodimer receptor, G-CSFR in order to perform its actions. It is mainly produced by hematopoietic cells like monocytes, macrophages and lymphocytes. It could be also produced by some other cells, like fibroblasts, endothelial cells, astrocytes, neurons, and bone marrow stromal cells ${ }^{[4]}$.

It has been reported that G-CSF has been considered as an important neurotrophic factor that can induce peripheral nerve protection and regeneration. Moreover, it enhances angiogenesis and has anti-apoptotic effect ${ }^{[5]}$.

Citrullus lanatus (watermelon) belongs to the Cucurbitaceae family. It has been extensively studied for its pharmacological and therapeutic activities such as antibacterial, antiulcer, antioxidant, anti-inflammatory, analgesic, hepatoprotective, and against prostatic hyperplasia and atherosclerosis ${ }^{[6]}$. Previous studies reported that citrullus lanatus had the ability to prevent oxidative injuries which could explain the mechanism of the action of this fruit in preventing and treating cardiovascular and neurodegenerative disorders ${ }^{[7]}$.

This work was performed to study the effect of cisplatin on the histological structure of cerebellar cortex of adult 
albino rat and the possible protective role of G-CSF versus citrullus lanatus (watermelon) juice.

\section{MATERIALS AND METHODS}

\section{Drugs}

\section{Cisplatin}

Generic name: Cisplatine, in the form of a vial $(50 \mathrm{mg} / 50 \mathrm{ml})$, Mylan S.A.S, France.

\section{Granulocyte Colony Stimulating Factor (G-CSF)}

Generic name: Neupogen, in the form of $0.5 \mathrm{ml}$ prefilled syringe containing $30 \mathrm{MU}$ (equal $300 \mu \mathrm{g}$ ) filgrastim (a recombinant-methionyl human granulocyte colony stimulating factor, r-metHuG-CSF, derived from Escherichia coli), F. Hoffmann-La Roche Ltd, Basel. Kirin-Amgen Inc.

\section{Citrullus Lanatus (watermelon) Juice}

It was freshly prepared daily from watermelon fruits (green skin and red flesh). They were bought from a fruit seller in a local market in Al Abour City, Cairo, Egypt. Preparation started by peeling the skin of the fruit and removing the seeds followed by chopping the mesocarp into thin slices and transforming it into juice using an electrical blender then a fine mesh was used to strain the liquid and get a clear fresh watermelon juice ${ }^{[8]}$.

\section{Animals}

This study was conducted on 40 adult male albino rats about 12 weeks old and weighing an average of 200 grams. They were bought from the Animal House of Kasr Al-Ainy and housed in hygienic stainless-steel cages in a clean well-ventilated room, at room temperature with free access to food and water. The study protocol followed the guidelines and was approved by the Institutional Animal Care and Use Committee of Cairo University. Approval Number of this experiment was CU III S 8617.

\section{Experimental Design}

Rats were randomly allocated into control and experimental groups:

\section{Control Group}

Included 16 rats that were subdivided equally into the following subgroups (4 rats each):

- Subgroup 1: serving as negative control, did not receive any intervention throughout the study duration.

- Subgroup 2: serving as control for group I. Each rat was given $2 \mathrm{ml}$ of saline intraperitoneal (IP) on day 6 and day 13 from the start of the experiment.

- Subgroup 3: serving as control for group II. Each rat was given $0.5 \mathrm{ml}$ of glucose $5 \%$ (dissolving vehicle for G-CSF) subcutaneous (SC) once daily for 5 consecutive days from the start of the experiment and then injected with $2 \mathrm{ml}$ of saline IP on day 6 and day 13.
- Subgroup 4: serving as control for group III Each rat received $0.8 \mathrm{ml}$ of distilled water by oral gavage once daily throughout the whole experimental period (16 days) and injected with 2 $\mathrm{ml}$ of saline IP on day 6 and day 13 from the start of the experiment.

\section{Experimental Groups}

Twenty-four rats were equally divided into the following 3 groups (8 rats each):

- Group I (cisplatin treated group): rats were injected with $10 \mathrm{mg} / \mathrm{kg}$ of cisplatin IP on the $6^{\text {th }}$ and the 13th days of the study ${ }^{[9]}$.

- Group II (cisplatin \& G-CSF treated group): rats received G-CSF $(50 \mu \mathrm{g} / \mathrm{kg})$ diluted in $0.5 \mathrm{ml}$ glucose $5 \%$ SC once daily for 5 consecutive days ${ }^{[10]}$ from the start of experiment then received cisplatin as in group I.

- Group III (cisplatin \& citrullus lanatus juice treated group): rats received watermelon juice by oral gavage at a dose of $4 \mathrm{ml} / \mathrm{kg}$ body weight once daily throughout the whole experimental period (16 days ${ }^{[8]}$. Cisplatin was given on days 6 and 13 as in group I.

- The experiment ended 3 days after the last cisplatin injection $^{[11]}$

Blood samples were collected from all rats, at the end of study period, from the tail vein to detect levels of malondialdehyde (MDA) and reduced glutathione $\mathrm{GSH}^{[12]}$. Blood samples were centrifuged at $3000 \mathrm{rpm}$ for 10 minutes at room temperature and stored at $-20^{\circ} \mathrm{C}$ until they were assayed. These measurements were done at Biochemistry and Molecular Biology unit of Medical Biochemistry department, Faculty of Medicine, Cairo University.

After blood collection, all rats were euthanized by IP injection of sodium pentobarbital $(100 \mathrm{mg} / \mathrm{kg})^{[13]}$. Then received an intracardiac injection of $1 \mathrm{ml}$ of $10 \%$ formalin. Skull of each animal was opened and cerebellum was immediately dissected out and divided into two hemispheres:

The right cerebellar hemisphere was subjected to fixation in $10 \%$ buffered formalin solution, dehydration in ascending grades of ethanol, embedding in paraffin and finally cutting into serial $5 \mu \mathrm{m}$-thick sections which were used for the following procedures:

1. Hematoxylin and Eosin staining for studying the histological structure of cerebellum ${ }^{[14]}$.

2. Immunohistochemical staining ${ }^{[15]}$ by avidin biotin peroxidase complex technique for the detection of:

- GFAP: to demonstrate astrocytes. Using anti-GFAP antibody, a mouse monoclonal antibody (Lab Vision Corporation laboratories, CA94539, USA, catalog number MS-1376-P0). 
- Caspase-3: to demonstrate cell apoptosis. Using anti-caspase-3 antibody, a rabbit polyclonal antibody (Lab Vision Thermo Fisher Scientific, USA, catalog number RB-1197-R7).

The sections for immunohistochemical stains were allowed to boil for $10 \mathrm{~min}$ in $10 \mathrm{mM}$ citrate buffer (AP9003) at $\mathrm{pH} 6$ for antigen retrieval then incubated for $1 \mathrm{~h}$ with the primary antibodies. Ultravision detection system (TP-015-HD) was used to complete immunostaining and Mayer's hematoxylin (TA-060-MH) was used for counterstaining. Citrate buffer, Ultravision detection system and Mayer's hematoxylin were purchased from Lab vision Thermo Scientific, Fremont, California, USA.

Negative controls were subjected to the same steps except the addition of the primary antibodies.

Positive immunoreaction for GFAP appeared in cytoplasm and processes as brown color and for caspase- 3 appeared in cytoplasm and in some nuclei as brown color.

The left cerebellar hemisphere was processed for preparing semithin and ultrathin sections for transmission electron microscopic examination ${ }^{[16]}$. Small pieces of cerebellar cortex, approximately $1 \mathrm{~mm}^{3}$, were subjected to fixation in $2.5 \%$ phosphate buffered glutaraldehyde (pH 7.4) at $4^{\circ} \mathrm{C}$ for two hours, rinsing in $0.1 \mathrm{M}$ phosphate buffer and post fixation in 1\% phosphate-buffered osmium tetroxide for one hour, then dehydration in ascending grades of ethanol. After transferring into propylene oxide and epoxy resin mixture, the specimens were embedded in fresh epoxy resin containing capsules. Semithin sections ( $1 \mu \mathrm{m}$ thick) were subjected to staining with $1 \%$ toluidine blue and examination by the light microscope. Ultrathin sections ( $80 \mathrm{~nm}$ thick) were subjected to staining with uranyl acetate and lead citrate then examination and photographing by a JEM-1400 transmission electron microscope (JEOL, Tokyo, Japan) at the Electron Microscopic Unit, Faculty of Agriculture, Research Park, Cairo University.

\section{Morphometric Study}

Ten non-overlapping fields from different sections of each rat of each group were used to measure:

- Number of Purkinje cells (x100) and thickness of granular layer (x100) using interactive measurements menu.

- Area percent of GFAP positive immunoreactive astrocytes $(\mathrm{x} 400)$ using binary mode.

- Optical density of caspase-3 positive immunoreactive cells $(\mathrm{x} 400)$ using color monomode.

Measurements were obtained using "Leica Qwin 500 C" image analyzer computer system Ltd. (Cambridge, England) in Histology Department, Faculty of Medicine, Cairo University.

\section{Statistical Analysis}

Data tabulation and analysis were performed using SPSS software version 21. The one-way analysis-ofvariance (ANOVA) followed by the post hoc Tukey test were used for comparison of quantitative data which were presented as means and standard deviations (SD). $P$-values $<0.05$ indicated a statistical significance ${ }^{[17]}$.

\section{RESULTS}

In the present work, no rats died and examination of all control subgroups revealed the same results.

\section{Biochemical Results}

Mean Plasma level of malondialdehyde (MDA) enzyme (Table 1 and Histogram 1):

The mean plasma level of MDA enzyme was significantly higher in group I than the control group. It was significantly lower in group II than both group I and group III, yet, non-significantly higher than the control group. Regarding group III, it was significantly lower than group I, but significantly higher than the control group.

Mean Plasma level of reduced glutathione (GSH) enzyme (Table 1 and Histogram 2):

The mean plasma level of GSH enzyme was significantly lower in group I than the control group. It was significantly higher in group II than both group I and group III, yet, non-significantly lower than the control group. Regarding group III, it was significantly higher than group I, but significantly lower than the control group.

\section{Light Microscopic Results}

\section{1- Hematoxylin and eosin stained sections (Figures 1 and 2)}

The cerebellar cortex of control rats demonstrated three layers: outer molecular, middle Purkinje cell, and inner granular layers. Purkinje cell layer was formed of a single row of Purkinje cells which were pyriform in shape with basophilic granular cytoplasm, central vesicular nuclei and prominent nucleoli. Granular layer was composed of numerous closely packed granule cells with dark rounded nuclei and acidophilic cerebellar areas in-between. Molecular layer showed basket cells and lightly acidophilic neuropil (Figures 1A and B).

Sections from group I showed irregular shaped deeply stained Purkinje cells with pyknotic nuclei. Some Purkinje cells were arranged into multiple layers and surrounded by vacuolated neuropil, while others appeared disorganized among widely separated granule cells (Figures $1 \mathrm{C}$ and D).

Group II revealed most of Purkinje cells appeared with more or less normal shapes, basophilic granular cytoplasm, vesicular nuclei and prominent nucleoli, while few still affected by cisplatin and appeared shrunken, darkly stained with pyknotic nuclei. Few pericellular halos appeared in molecular layer (Figure $2 \mathrm{~A}$ ). 
Group III showed some Purkinje cells appeared with more or less normal shapes, basophilic granular cytoplasm and vesicular nuclei while others still appeared shrunken, with irregular shapes, deeply stained cytoplasm and pyknotic nuclei. There was vacuolated neuropil in Purkinje cell layer and some vacuolation in molecular layer (Figure 2 B).

\section{2- Immunohistochemically stained sections for GFAP (Figure 3)}

The cerebellar cortex of rats of control group demonstrated few GFAP positive astrocytes in granular, molecular and Purkinje cell layers (Figure 3A). Group I showed multiple GFAP positive astrocytes in all layers of cerebellar cortex (Figure 3B). In group II, few GFAP positive astrocytes appeared in all layers (Figure 3C). Meanwhile, group III revealed some GFAP positive astrocytes in cerebellar cortical layers (Figure 3D).

\section{3-Immunohistochemically stained sections for caspase-3 (Figure 4)}

The cerebellar cortex of rats of control group demonstrated negative caspase-3 immunoreaction in cells of granular, molecular and Purkinje cell layers (Figure 4A). Group I showed obvious caspase-3 immunoreactivity in cells of granular and Purkinje cell layers (Figure 4B). Faint caspase-3 immunoreactivity was detected in cells of cerebellar cortical layers of group II (Figure 4C). Group III revealed less obvious caspase-3 immunoreactivity in cells of layers of cerebellar cortex (Figure 4D).

\section{4- Semithin sections stained with toluidine blue (Figure 5)}

The semithin sections of cerebellar cortex of control rats revealed Purkinje cells with central vesicular nuclei, cytoplasmic Nissl granules and surrounded by pale-stained Bergmann astrocytes. Granule cells appeared densely populated with darkly stained nuclei and scanty cytoplasm (Figure 5A). Group I showed deformed Purkinje cells with deeply stained cytoplasm, surrounded by multiple focal vacuoles and appeared disorganized among granule cells. Some granule cells were darkly stained (Figure 5B).

Examination of group II showed Purkinje cells arranged in one row with more or less uniform shape and size, granular cytoplasm with Nissl granules and pale nuclei. Few vacuoles appeared in surrounding neuropil and some neuroglia showed irregular outline (Figure 5C). Group III revealed Purkinje cells with more or less regular shape and size, granular cytoplasm with Nissl granules and pale nuclei. Some Purkinje cells showed primary dendritic processes arising from their perikarya, other cells appeared shrunken (Figure 5D).

\section{Electron Microscopic Results (Figures 6 and 7)}

The ultrathin sections of cerebellar cortex of control rats demonstrated Purkinje cells with euchromatic nuclei, cytoplasm containing cisternae of rough endoplasmic reticulum, free ribosomes, Golgi apparatus, and multiple mitochondria (Figure 6A). Granule cells appeared closely packed with nuclei containing clumps of heterochromatin. Each nucleus was surrounded by a thin rim of cytoplasm with mitochondria and free ribosomes. The granular layer showed also myelinated nerve fibers with regular compact myelin sheath and multiple mitochondria in the axoplasm (Figure 6B).

Group I exhibited part of a Purkinje cell with shrunken irregular nucleus, dilated Golgi apparatus and numerous swollen mitochondria with destroyed cristae (Figure 6C). Granule cells looked shrunken with irregular shapes and irregular dark shrunken nuclei. Myelinated nerve fibers of granular layer revealed splitting and disruption of myelin sheath. Some mitochondria in the neuropil showed destroyed cristae (Figure 6D).

Examination of group II showed apparently normal Purkinje cells with euchromatich nuclei. The cytoplasm showed most mitochondria with regular cristae while others with destroyed cristae. Cisternae of rough endoplasmic reticulum and free ribosomes were roughly similar to the control group (Figure 7A). Granule cells were nearly the same as those of the control group with nuclei containing clumps of heterochromatin. Nuclei were surrounded by thin rim of cytoplasm containing mitochondria and free ribosomes. Few vacuolation was detected in neuropil between the granule cells. Most of myelinated nerve fibers demonstrated regular compact myelin sheath with mitochondria within axoplasm (Figure 7B).

Meanwhile, group III showed Purkinje cells with irregular nuclei, normal cisternae of rough endoplasmic reticulum, free ribosomes and Golgi saccules. Few mitochondria had regular cristae while others appeared swollen with destroyed cristae (Figure 7C). Closely packed granule cells exhibited nuclei with clumps of heterochromatin and a thin rim of cytoplasm with areas of rarefaction. Myelin sheath of some nerve fibers in granular layer appeared regular compact and of low electron density (Figure 7D).

\section{Morphometric and statistical results (Table 2 and Histograms 3-6)}

The mean number of Purkinje cells and the mean thickness of granular layer were significantly lower in group I than the control group. In group II, they were significantly higher than groups I and III and non-significantly lower than the control group. Regarding group III, they were significantly higher than group I, but significantly lower than the control group.

Concerning the mean area percent of GFAP positive astrocytes and the mean optical density of caspase-3 positive cells, group I showed significantly higher data than the control group. While group II revealed significantly lower data than groups I \& III, yet non-significantly higher than the control group. Regarding group III, they were significantly lower than group I, but significantly higher than the control group. 

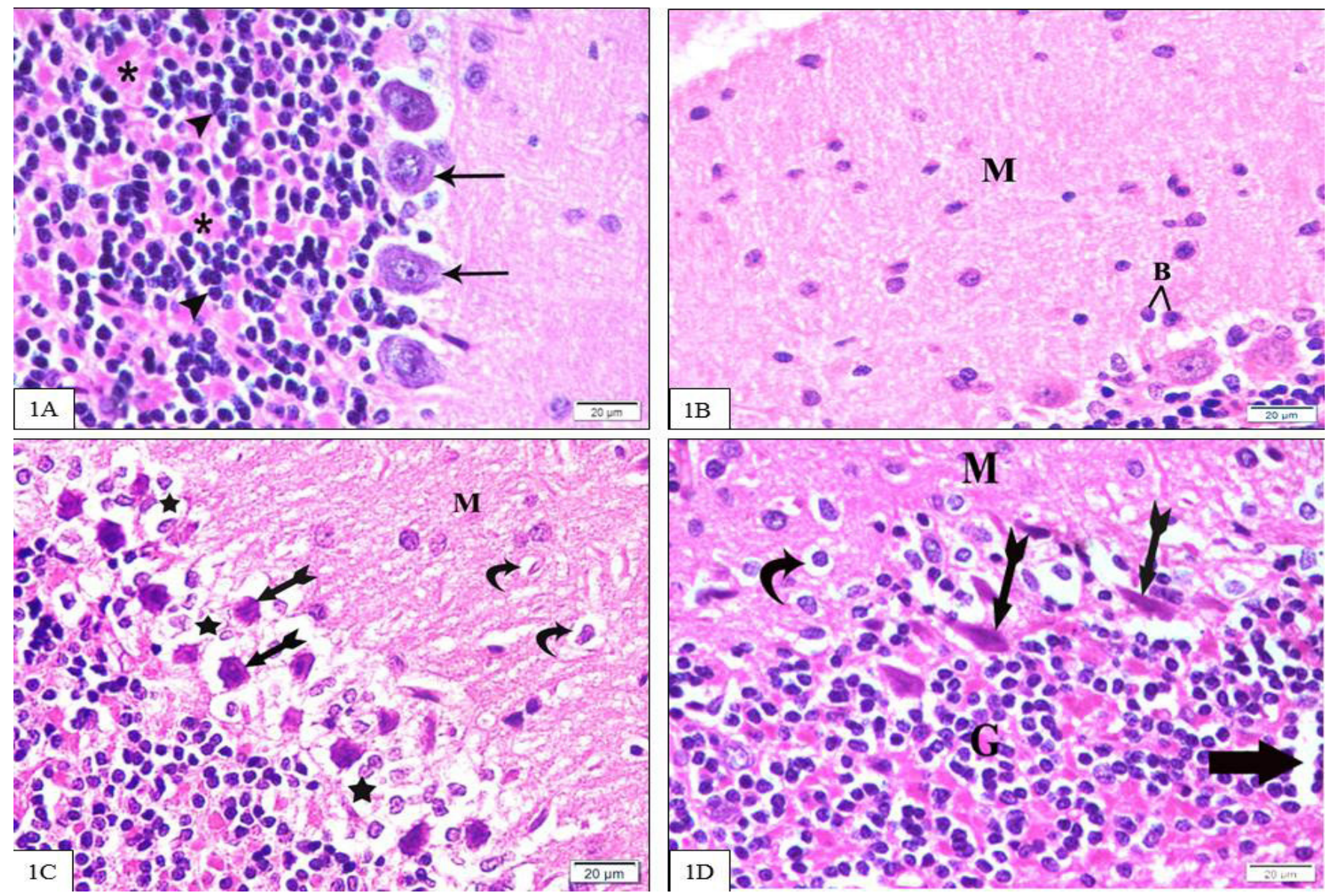

Fig. 1: Photomicrographs of sections in cerebellar cortex of rats stained with H\&E (x400) (1A): control group showing pyriform shaped Purkinje cells (arrows) arranged in one row with basophilic granular cytoplasm, central vesicular nuclei and prominent nucleoli. Granule cells (arrow heads) appear numerous, closely packed with dark rounded nuclei and acidophilic cerebellar areas (asterisks) in-between. (1B): control group showing molecular layer (M) with basket cells (B) and lightly acidophilic neuropil (1C): group I showing irregular shaped deeply stained Purkinje cells with pyknotic nuclei (bifid arrows) arranged in multiple layers and surrounded by vacuolated neuropil (stars). Notice pericellular halos (curved arrows) in molecular layer (M). (1D): group I showing disorganized distorted irregular shaped Purkinje cells (bifid arrows) among cells of granular layer (G), widely separated granule cells (thick arrow) and pericellular halos (curved arrow) in molecular layer (M)
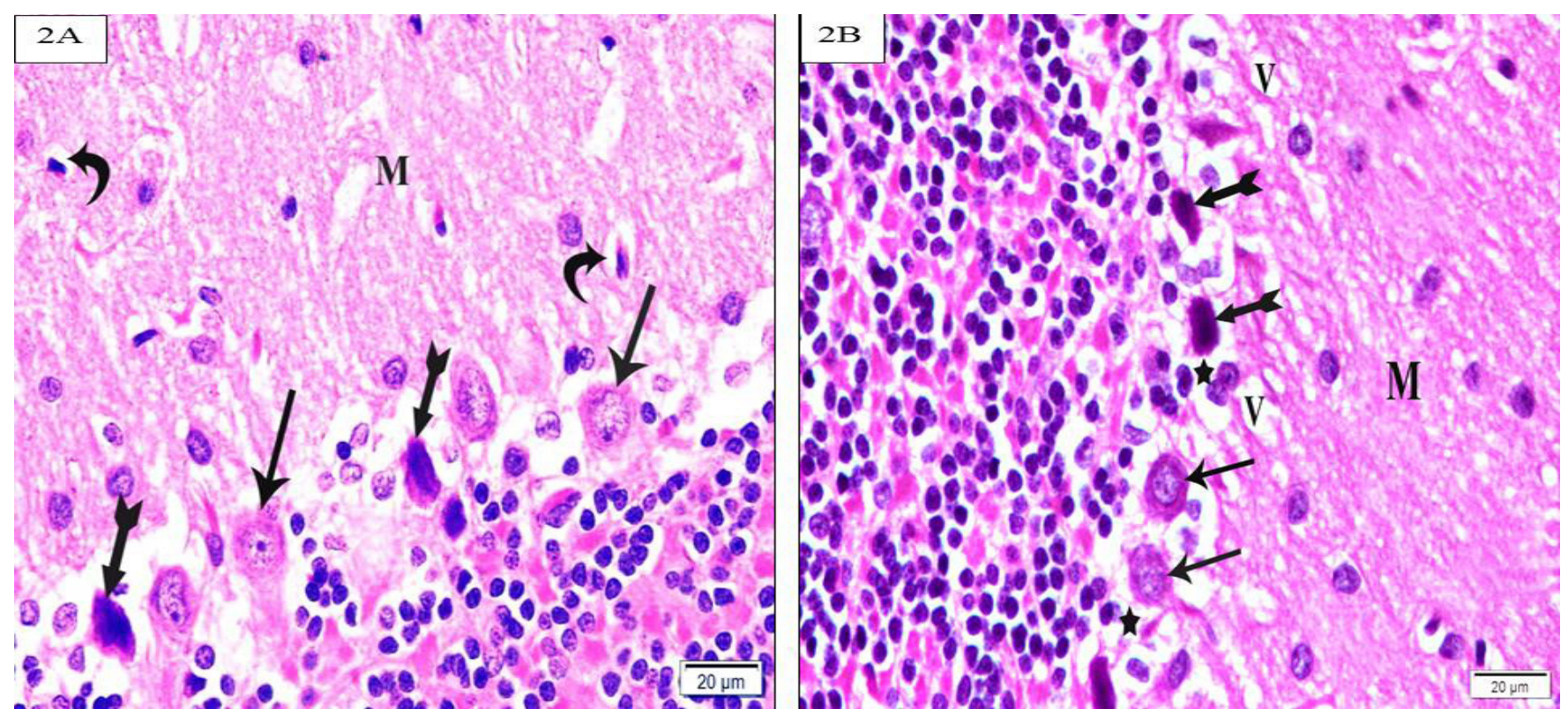

Fig. 2: Photomicrographs of sections in cerebellar cortex of rats stained with H\&E (x400) (2A): group II showing most of Purkinje cells (arrows) appearing with normal shapes, basophilic granular cytoplasm, vesicular nuclei and prominent nucleoli, while few appear shrunken, darkly stained with pyknotic nuclei (bifid arrows). Few pericellular halos (curved arrows) appear in molecular layer (M). (2B): group III showing some Purkinje cells (arrows) with normal appearance with basophilic granular cytoplasm and vesicular nuclei. Others (bifid arrows) are deeply stained, shrunken and irregular in shape with pyknotic nuclei. Notice vacuolated neuropil (stars) in Purkinje cell layer and some vacuolation (V) in molecular layer (M). 

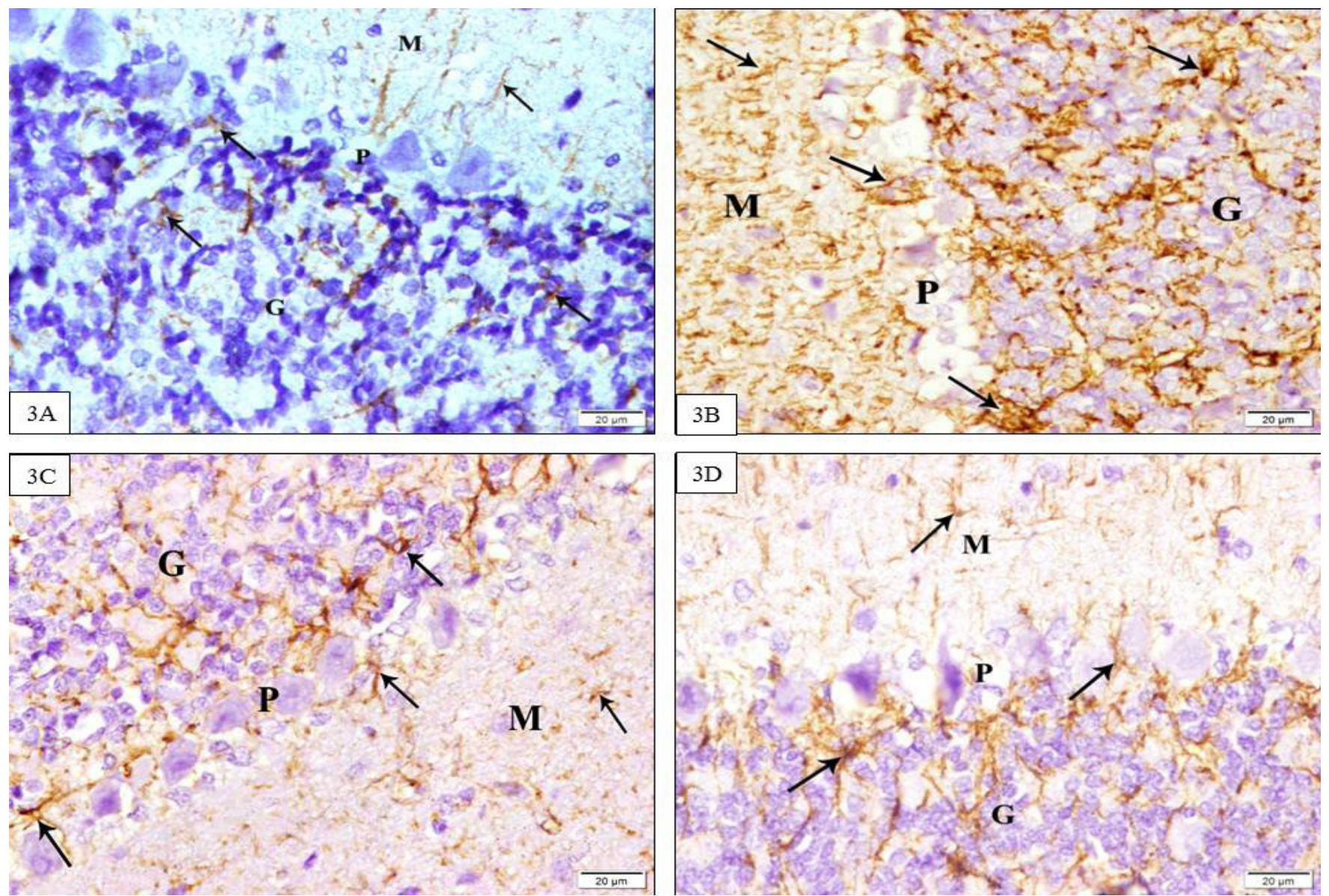

Fig. 3: Photomicrographs of sections in cerebellar cortex of rats stained with GFAP immunostaining (x400) demonstrating granular (G), molecular (M) and Purkinje (P) cell layers (3A): control group showing few GFAP positive astrocytes (arrows). (3B): group I showing multiple GFAP positive astrocytes (arrows) (3C): group II showing few GFAP positive astrocytes (arrows). (3D): group III showing some GFAP positive astrocytes (arrows).
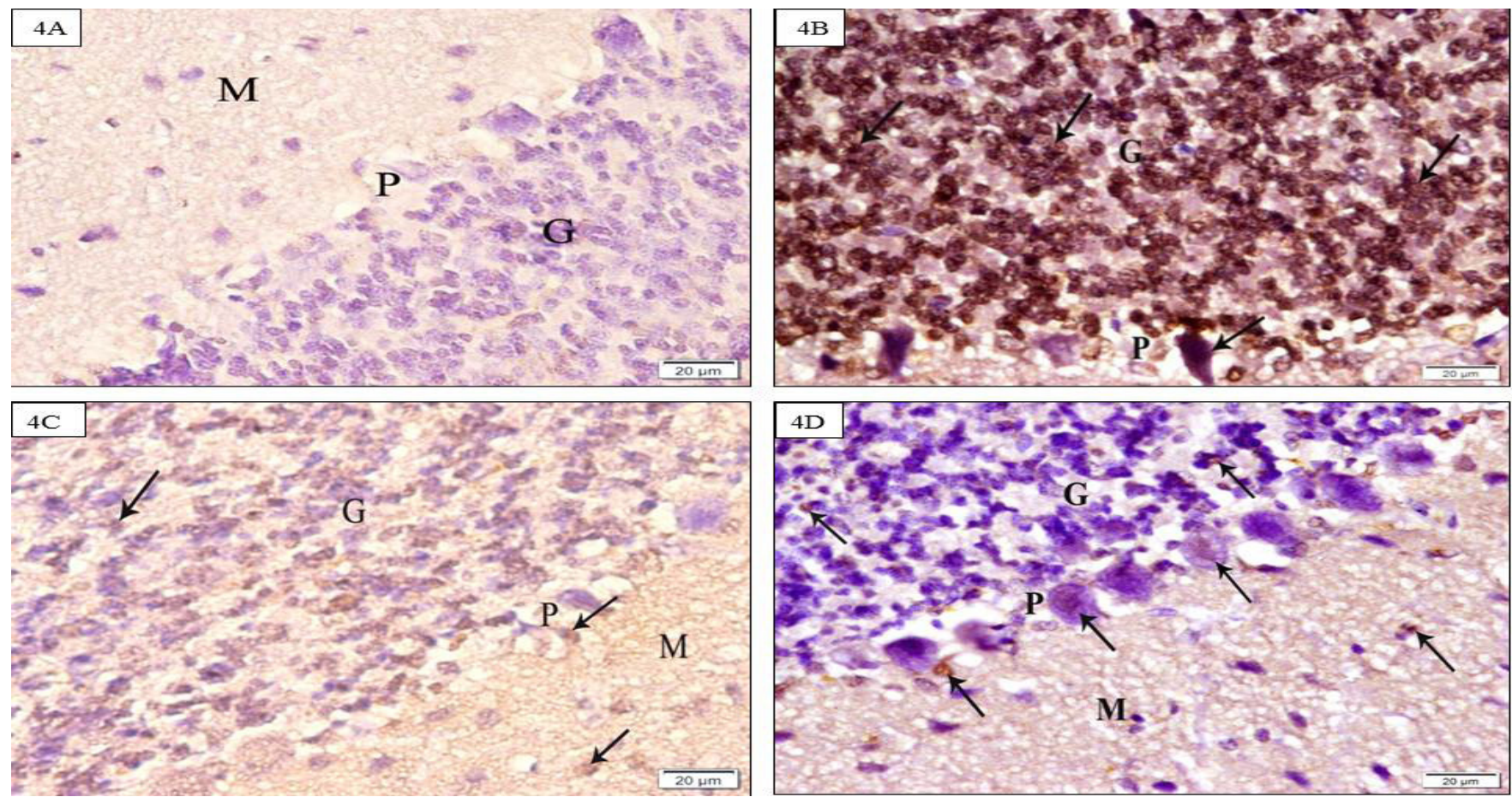

Fig.4: Photomicrographs of sections in cerebellar cortex of rats stained with caspase-3 immunostaining (x400) (4A): control group showing negative caspase-3 immunoreaction in cytoplasm and nuclei of cells in granular $(\mathrm{G})$, molecular (M) and Purkinje cell (P) layers. (4B): group I showing obvious caspase-3 immunoreactivity in cells (arrows) of granular $(\mathrm{G})$ and Purkinje cell (P) layers. (4C): group II showing faint caspase-3 immunoreactivity in cells (arrows) of granular (G), molecular (M) and Purkinje cell (P) layers. (4D): group III showing less obvious caspase-3 immunoreactivity in cells (arrows) of granular (G), molecular (M) and Purkinje cell (P) layers. 

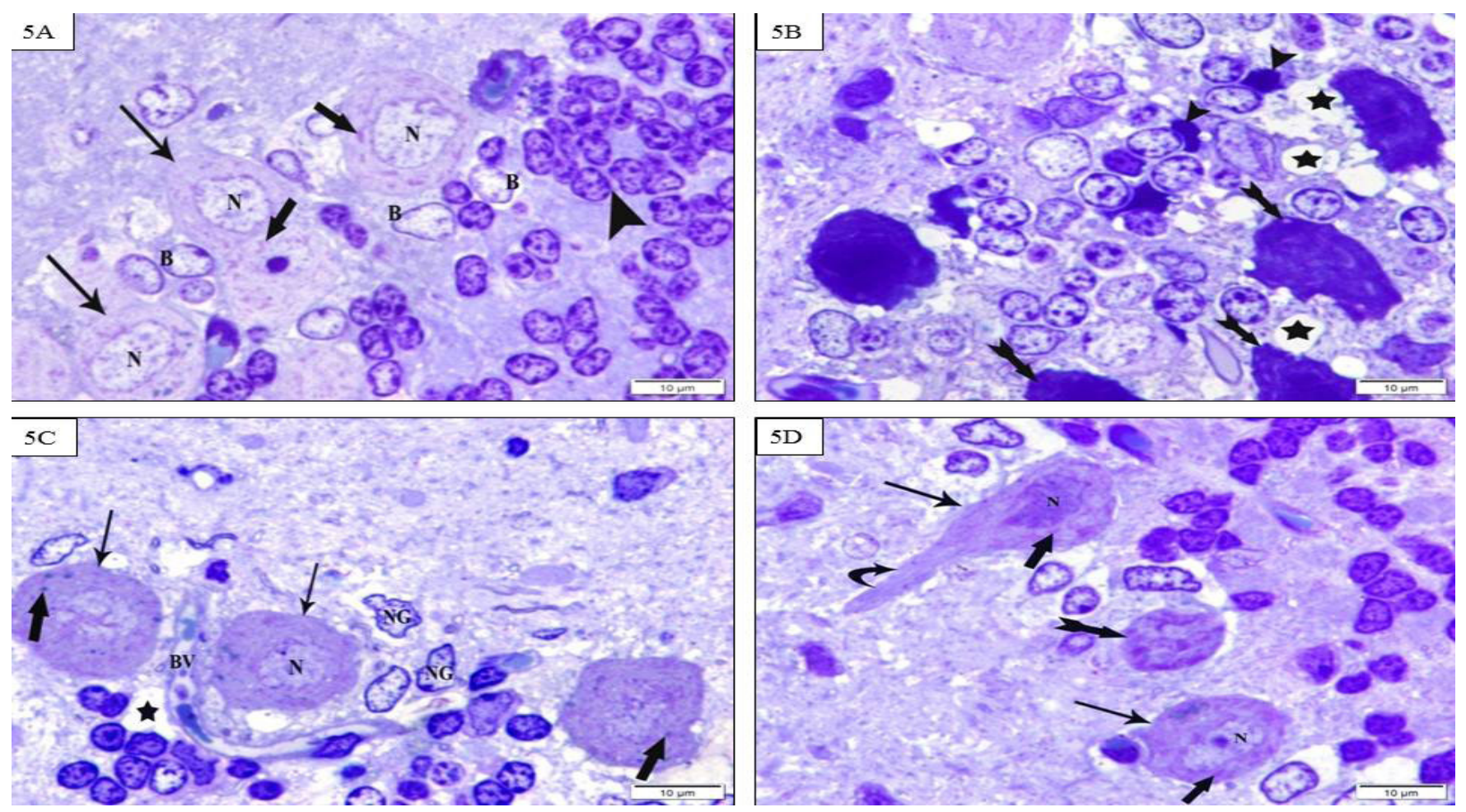

Fig. 5: Photomicrographs of semithin sections in cerebellar cortex of rats stained with toluidine blue (x1000) (5A): control group showing Purkinje cells (thin arrows) with central vesicular nuclei (N), cytoplasmic Nissl granules (thick arrows) and surrounded by pale-stained Bergmann astrocytes (B). Granule cells (arrow head) appear densely populated with darkly stained nuclei and scanty cytoplasm. (5B): group I showing deformed Purkinje cells with deeply stained cytoplasm (bifid arrows), surrounded by multiple focal vacuoles (stars) and appear disorganized among granule cells, some appear darkly stained (arrow heads). (5C): group II showing Purkinje cells (arrows) arranged in one row with uniform shape and size, granular cytoplasm with Nissl granules (thick arrows) and pale nuclei (N). Few vacuoles (star) appear in surrounding neuropil. Some neuroglia (NG) show irregular outline. Notice a blood vessel (BV). (5D): group III showing two Purkinje cells (thin arrows) with uniform shape and size, granular cytoplasm with Nissl granules (thick arrows) and pale nuclei (N), one shows a primary dendritic process (curved arrow) arising from its perikaryon. Another Purkinje cell (bifid arrow) appears shrunken.
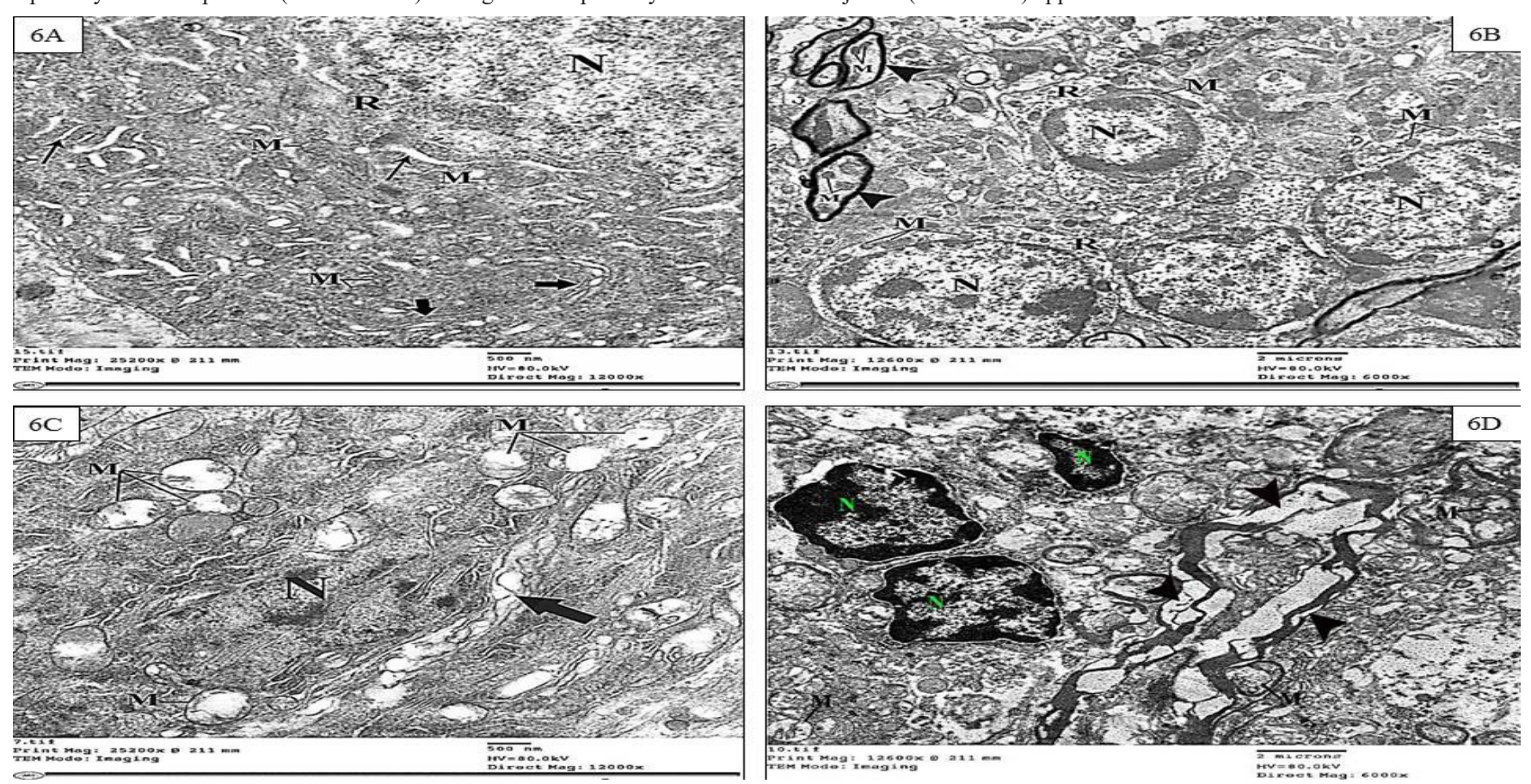

Fig. 6: Electron micrographs of sections in cerebellar cortex of rats (6A): control group showing part of the euchromatic nucleus (N) of Purkinje cell, cisternae of rough endoplasmic reticulum (thin arrows), free ribosomes (R), multiple mitochondria (M) and Golgi apparatus (thick arrows) (x12000). (6B): control group showing closely packed granule cells with nuclei $(\mathrm{N})$ containing clumps of heterochromatin and surounded by thin rim of cytoplasm containing mitochondria (M) and free ribosomes (R). Myelinated nerve fibers appear with regular compact myelin sheath (arrow heads) and multiple mitochondria (M) in the axoplasm (x6000). (6C): group I showing part of a Purkinje cell with shrunken irregular nucleus (N), dilated Golgi apparatus (arrow) and numerous swollen mitochondria (M) with destroyed cristae (x12000). (6D): group I showing granule cells appear shrunken irregular in shape with irregular dark shrunken nuclei (N). Myelinated nerve fibers appear with splitting and disruption of myelin sheath (arrow heads). Some mitochondria (M) in the neuropil show destroyed cristae (x6000). 

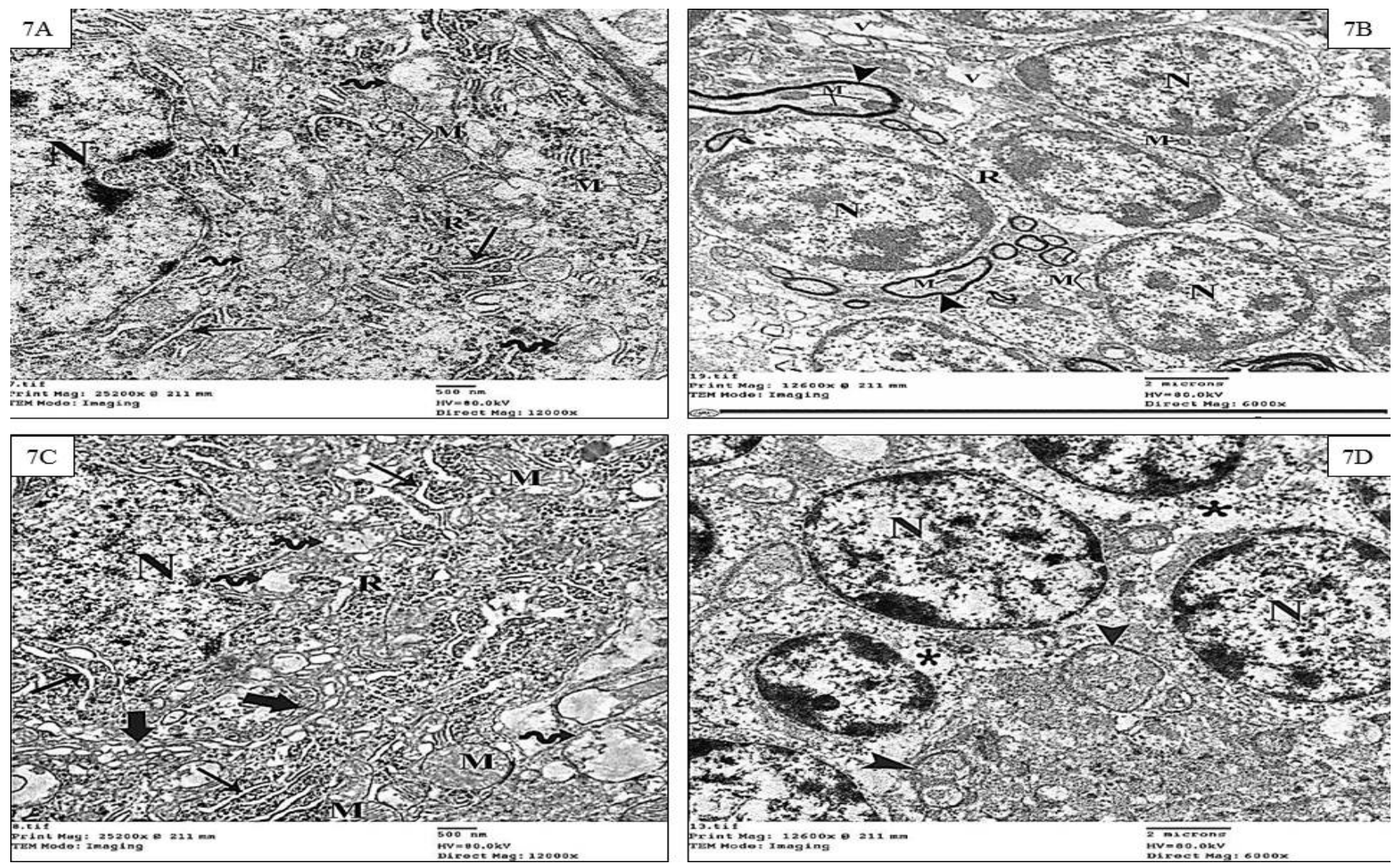

Fig. 7: Electron micrographs of sections in cerebellar cortex of rats (7A): group II showing part of the euchromatic nucleus (N) of a Purkinje cell, cisternae of rough endoplasmic reticulum (thin arrows), free ribosomes (R) and multiple mitochondria (M) with regular cristae. Some mitochondria (wavy arrows) show damaged cristae (x12000). (7B): group II showing granule cell nuclei (N) with clumps of heterochromatin and surrounded by thin rim of cytoplasm containing mitochondria (M) and free ribosomes (R). Myelinated nerve fibers have regular compact myelin sheath (arrow heads) with mitochondria (M) within axoplasm and few vacuolations of neuropil (V) (x6000). (7C): group III showing part of an irregular nucleus (N) of a Purkinje cell, apparently normal cisternae of rough endoplasmic reticulum (thin arrows), free ribosomes (R), and Golgi saccules (thick arrows). Few mitochondria (M) appear with regular cristae, while others (wavy arrows) appear swollen with destroyed cristae (x12000). (7D): group III showing closely packed granule cells with nuclei (N) having clumps of heterochromatin and surrounded by thin rim of cytoplasm. Areas of rarefied cytoplasm (asterisks) are seen. Myelin sheath of some myelinated nerve fibers appear regular compact and of low electron density (arrow heads) (x6000).

Table 1: The mean plasma level of MDA $(\mathrm{nmol} / \mathrm{ml})$ and GSH enzymes $(\mathrm{mmol} / \mathrm{L}) \pm \mathrm{SD}$ of control and experimental groups

\begin{tabular}{ccc}
\hline Groups & MDA & GSH \\
\hline Control & $10.42 \pm 0.63$ & $57.1 \pm 1.75$ \\
Group I & $25.38 \pm 1.47^{*}$ & $25.53 \pm 6.52^{*}$ \\
Group II & $12.72 \pm 1.05^{\text {\$\# }}$ & $50.01 \pm 2.59^{\text {\$\# }}$ \\
Group III & $17.43 \pm 2.42^{* \$}$ & $42.28 \pm 5.17^{* \$}$ \\
\hline Significant results at $P<0.05$ & SD: standard deviation \\
* Significant to control group. & \$ Significant to group I. \\
\# Significant to group III. &
\end{tabular}

Table 2: Morphometric and statistical results

\begin{tabular}{|c|c|c|c|c|}
\hline Groups & $\begin{array}{c}\text { Mean number } \\
\text { of Purkinje cells } \pm \text { SD }\end{array}$ & $\begin{array}{l}\text { Mean thickness of } \\
\text { granular layer } \pm \mathrm{SD}\end{array}$ & $\begin{array}{c}\text { Mean area } \% \text { of GFAP } \\
\text { positive astrocytes } \pm \text { SD }\end{array}$ & $\begin{array}{l}\text { Mean optical density } \\
\text { of caspase- } 3 \text { positive } \\
\text { cells } \pm \text { SD }\end{array}$ \\
\hline Control & $10.1 \pm 1.66$ & $282.81 \pm 49.98$ & $0.99 \pm 0.23$ & $0.29 \pm 0.06$ \\
\hline Group I & $3.9 \pm 0.87^{*}$ & $125.13 \pm 15.49^{*}$ & $3.91 \pm 0.47^{*}$ & $0.56 \pm 0.02^{*}$ \\
\hline Group II & $8.5 \pm 1.64^{\mathrm{S \#}}$ & $235.98 \pm 48.89^{\S \sharp}$ & $1.32 \pm 0.42^{\mathrm{SH}}$ & $0.34 \pm 0.07^{\mathrm{S} \#}$ \\
\hline Group III & $5.7 \pm 1.41^{* s}$ & $178.22 \pm 45.02^{* \$}$ & $1.98 \pm 0.24^{* \$}$ & $0.46 \pm 0.02^{* \$}$ \\
\hline
\end{tabular}

Significant results at $P<0.05$

SD: standard deviation

* Significant to control group.

\$ Significant to group I.

\# Significant to group III. 


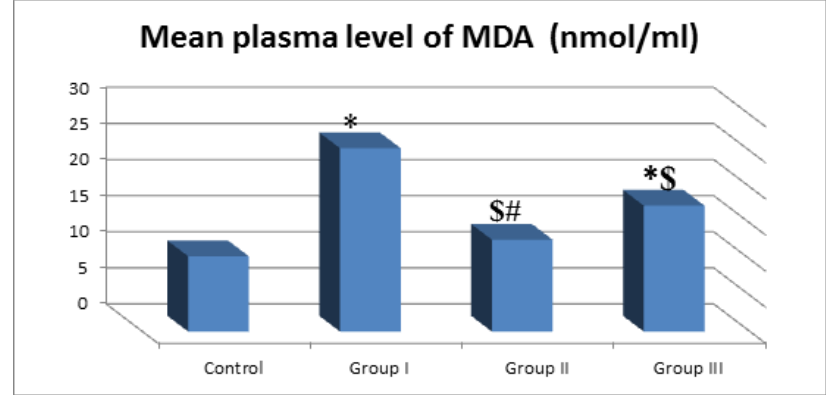

Histogram 1: The mean \pm SD of plasma level of MDA enzyme (nmol/ml) of control and experimental groups.

Significant results at $P<0.05$

* Significant to control group.

\$ Significant to group I.

\# Significant to group III.

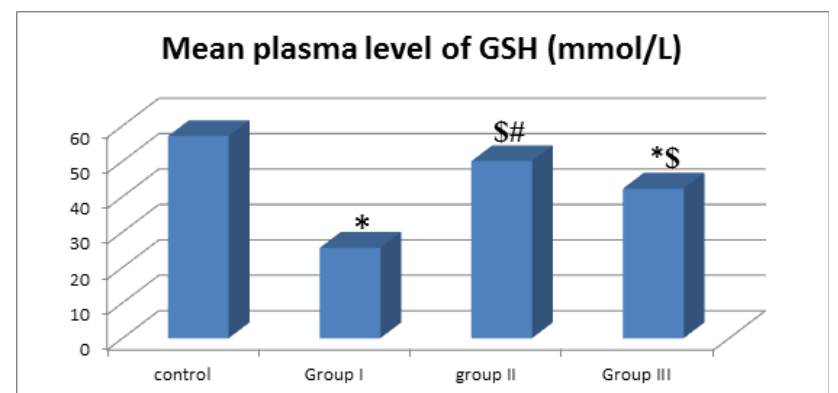

Histogram 2: The mean \pm SD of plasma level of GSH enzyme (mmol/L) of control and experimental groups.

Significant results at $P<0.05$

* Significant to control group.

\$ Significant to group I.

\# Significant to group III.

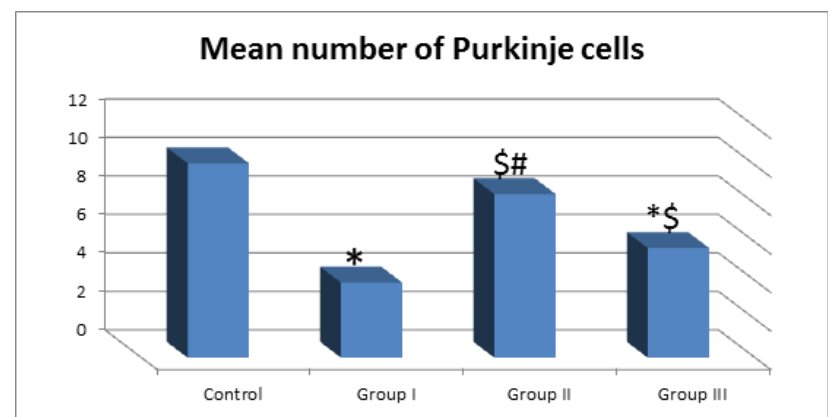

Histogram 3: The mean \pm SD of number of Purkinje cells of control and experimental groups.

Significant results at $P<0.05$

* Significant to control group.

\$ Significant to group I.

\# Significant to group III.

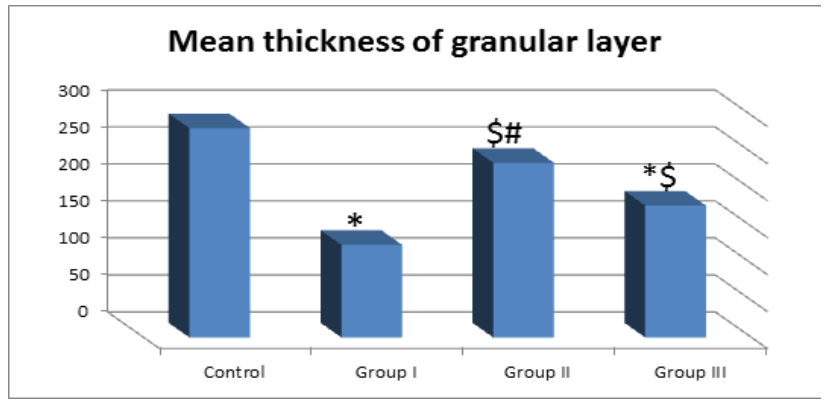

Histogram 4: The mean \pm SD of thickness of granular layer (in micrometer) of control and experimental groups.

Significant results at $P<0.05$

* Significant to control group

\$ Significant to group I.

\# Significant to group III.

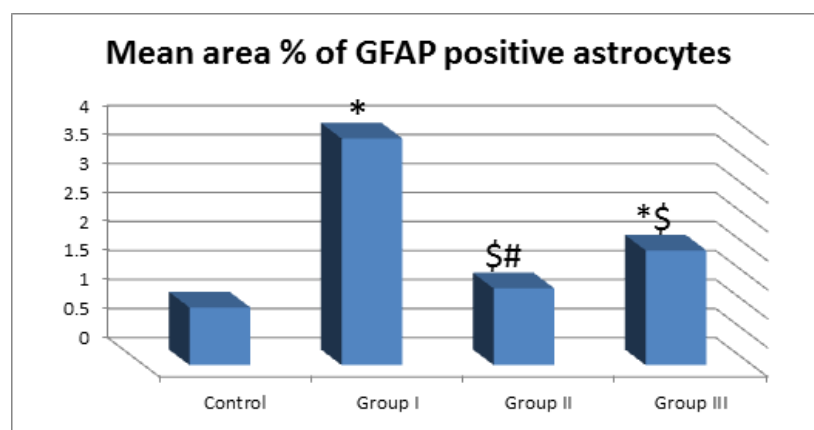

Histogram 5: The mean \pm SD of area percent of GFAP positive astrocytes of control and experimental groups.

Significant results at $P<0.05 \quad *$ Significant to control group.

\$ Significant to group I.

\# Significant to group III.

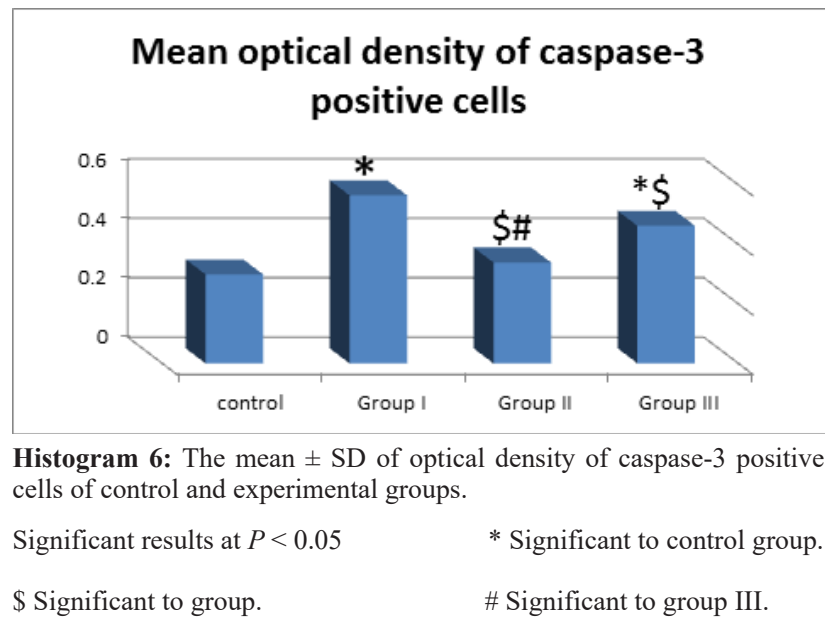




\section{DISCUUSION}

The clinical use of cisplatin as very effective antineoplastic drug is limited for being toxic to most human body organs and systems ${ }^{[18,19]}$. Neurotoxicity is the most significant that hinder its clinical use ${ }^{[20]}$. Although cisplatin-induced peripheral neurotoxicity and the role of protective agents have been the focus of many previous studies $^{[21,22]}$, a little light has been shed on its central neurotoxicity ${ }^{[23]}$.

The present work was done to study the impact of cisplatin on histological structure of rat cerebellar cortex and the possible protective role of G-CSF compared to citrullus lanatus juice in rat cerebellar injury under the effect of cisplatin.

The current study demonstrated a statistically significant rise in the level of malondialdehyde (MDA) (as a lipid peroxidation detector) and reduction in the level of reduced glutathione (GSH) (as an antioxidant defense agent) in group I in comparison to the control group. This laboratory result agrees with many previous studies ${ }^{[24,25]}$.

Oxidative stress is an important mechanism of cisplatin induced neurotoxicity. Cisplatin induces formation of reactive oxygen species (ROS) and the free oxygen radicals and, at the same time, reduces the production of antioxidants disturbing the oxidant/antioxidant balance and triggering lipid membrane peroxidation as well as tissue damage $e^{[26,27]}$.

In the present study, $H \& E$ and toluidine blue stained cerebellar sections of group I revealed most of the Purkinje cells appeared shrunken distorted with dark cytoplasm, pyknotic nuclei and surrounded with vacuolated neuropil. Their linear organization was disturbed; some appeared disorganized among granule cells while others were arranged in multiple layers. Statistical significant decrease in mean number of Purkinje cells was detected as compared with those of control rats. Similar results were obtained by other authers ${ }^{[28-30]}$.

Dark Purkinje cells with pyknotic nuclei could be attributed to apoptosis induced by cisplatin ${ }^{[31]}$. Darkly stained degenerated cells could be explained by accumulated denatured proteins resulting from cisplatin induced oxidative stress $^{[32,33]}$. Loss of pyriform shape of Purkinje cell bodies could be explained by the ability of cisplatin to interact with cytoskeletal elements ${ }^{[34]}$. Shrinkage of cells and loss of their cellular processes could explain appearance of separated neuropil around Purkinje cells in this study ${ }^{[35]}$

Disturbed linear organization of Purkinje cells could be explained by previous researchers who reported that prolonged neuronal insult might result in adaptive mechanism in the form of Purkinje cell crowding in other areas as a trial to reestablish synapsis with other nerve cells to achieve their functions ${ }^{[36]}$.
Granular layer in group I displayed separation between granule cells. In addition, there was a decrease in granular layer thickness that was confirmed statistically. Similar findings were observed by other authors ${ }^{[37,38]}$ on studying the damaging effects of morphine and sodium fluoride respectively on cerebellum. Decreased thickness of granular layer could be explained by neuronal loss ${ }^{[39]}$.

In the present study, GFAP stained cerebellar sections of group I revealed multiple astrocytes with positive immunoreaction. This was confirmed statistically as a significant increase in mean area percent of GFAP positive astrocytes. This finding was supported by Wallauer et al., ${ }^{[40]}$ who found that astrocytes became activated increasing their number and size as well as the expression of their cytoskeletal GFAP on exposure to ethanol injury.

CNS injuries induce molecular, morphological and functional changes of astrocytes called reactive astrogliosis. The mechanism of this gliosis is due to oxidative stress and elevation of $\operatorname{ROS}^{[41]}$. Consequently, astrocytes release neurotoxic substances such as free radicles and inflammatory cytokines that actively attack protein molecules within neurons, resulting in neuronal damage ${ }^{[42]}$.

Obvious caspase- 3 immunoreaction in cells of group I was confirmed statistically by significant increase in its mean optical density. Some authors agreed with this result ${ }^{[43]}$. Cisplatin has been confirmed to be a DNA targeting agent inducing DNA damage and apoptosis due to formation of toxic platinum DNA adducts, such as monoadducts and cross-links ${ }^{[44]}$. These adducts not only formed with nuclear DNA, but also with mitochondrial DNA resulting in inhibition of mitochondrial DNA replication and mitochondrial genes transcription ${ }^{[45,46]}$.

In the current study, the major ultrastructural changes in group I were in the form of irregular Purkinje cells with irregular shrunken nuclei, dilated Golgi apparatus and swollen mitochondria with destroyed cristae. Similar observations have been reported by other authors ${ }^{[47,48]}$.

Lomeli et al. ${ }^{[49]}$ found that acute cisplatin treatment induced mitochondrial degradation, vacuolization and loss of cristae in CA3 hippocampal neurons. It was reported that cisplatin rapidly increased mitochondrial accumulation of p53 in dorsal root ganglia, spinal cord, and peripheral nerves. P53 accumulation caused apoptotic death of the injured cells. In addition, cisplatin reduced mitochondrial membrane potential led to abnormal morphology and disorganized cristae ${ }^{[50]}$. Stressed mitochondria would release cytochrome c (part of mitochondrial electron transport chain) into cytoplasm to activate caspase-3 and subsequently induce cell death ${ }^{[51]}$.

Ultrastructurally, granule cells of group I appeared irregular shrunken. Their nuclei were irregular with dense heterochromatin. Similar results obtained by Mohamed 
and Mohamed ${ }^{[52]}$ on studying effect of gibberellic acid on cerebellum. Degenerative changes in granule cells were considered to be secondary to those of Purkinje cells as they failed to make normal contact with granule cells ${ }^{[36]}$. Moreover, splitting and disruption of myelinated nerve fibers was also detected by some researchers who found that cisplatin induced focal areas of demyelination and degeneration of nerve fibers ${ }^{[53]}$.

Myelin breakdown due to toxic agents altered osmotic conditions to such an extent that water and electrolytes were drawn into myelin sheath leading to edema and myelin splits. Similar processes could contribute to myelin splitting and disruption from cisplatin ${ }^{[54]}$. Myelin damage might also result from decreased myelin-associated glycoprotein, axonal degeneration, autoantibodies to myelin basic protein, and impairment of oligodendrocyte function ${ }^{[55]}$.

In group II of the current study, a noticeable improvement was evident in biochemical, histological and statistical findings. In this regard, it was reported that G-CSF exerted potential protective role for traumatic brain injury ${ }^{[56]}$ and renal tubular injury induced by cisplatin ${ }^{[57]}$.

Administration of G-CSF decreased the level of MDA and lipid peroxidation as well as enhanced myelin regeneration as reported in some studies including spinal cord and brain injuries. The protective action of G-CSF against cisplatin-induced cerebellar damage could be owed to its antioxidant effect ${ }^{[58]}$, it could effectively prevent oxidative stress induced ROS production, mitochondrial membrane potential changes and swelling ${ }^{[59]}$.

Moreover, it was evidenced that G-CSF decreased expression of GFAP in a mice model of spinocerebellar $\operatorname{ataxia}^{[60]}$. Anti-apoptotic effect of G-CSF was detected in rat cortical neurons treated with staurosporine ${ }^{[61]}$ and after spinal cord injury as it decreased number of caspase- 3 positive cells ${ }^{[62]}$.

Granulocyte colony stimulating factor could cross blood brain barrier and act on neurons and glial cells through G-CSF receptors ${ }^{[63,64]}$. Activation of these receptors was proved to down regulate pro-inflammatory cytokines, increase neurogenesis, trigger anti-apoptotic pathways and promote cerebral angiogenesis, together with ameliorating sensory and motor deficits in ischemic injuries ${ }^{[65,66]}$. Moreover it had the ability to stimulate stem cells mobilization and homing to brain with neuronal differentiation ${ }^{[67]}$

In the present work, biochemical, histological and statistical results of group III exhibited partial improvement as compared to group II. Improvement of changes in group III could be explained by the phytochemical antioxidant effect of citrullus lanatus juice that antagonized oxidative damage ${ }^{[68]}$. This was in agreement with Asita \& Molise ${ }^{[69]}$ and Naz et al., ${ }^{[70]}$ who revealed that watermelon contained higher content of carotenoids such as lycopene which was an excellent antioxidant.
Lycopene consumption was reported to reduce the risk of chronic disorders like cardiovascular, neurodegenerative and inflammatory diseases ${ }^{[71]}$. Lycopene has been proven to be a major free radical scavenger and a highly effective antioxidant ${ }^{[72]}$. Moreover, it was proved to attenuate nephrotoxicity induced by cisplatin ${ }^{[73]}$.

It was noticed that the group treated with cisplatin and G-CSF showed better improvement than the group treated with cisplatin and citrullus lanatus juice. This improvement was detected in all parameters used and confirmed statistically throughout the current work. This might be due to the multiple mechanisms by which G-CSF acted on the tissues. Teixeira et al., ${ }^{[74]}$ mentioned that G-CSF had antioxidant and anti-apoptotic effects as well as it enhanced stem cell mobilization, neurogenesis and angiogenesis. Meanwhile, citrullus lanatus juice operated through its antioxidant mechanism ${ }^{[75]}$.

\section{CONCLUSION}

- Cisplatin had neurotoxic effect on all layers of the grey matter

- Co-administration of granulocyte colony stimulating factor (G-CSF) with cisplatin ameliorated to great extent the harmful effect of cisplatin on the histological structure of cerebellar cortex.

- Citrullus lanatus juice when administrated with cisplatin had less role in protecting cerebellar components as neurons and in preventing reactive gliosis when compared to G-CSF.

\section{CONFLICTS OF INTEREST}

There are no conflicts of interest.

\section{REFERNCES}

1. Katzung BG and Trevor AJ: Cancer Chemotherapy. In: Basic and Clinical pharmacology, 13th ed. McGraw-Hill Education. New York, Chicago. 2015; pp: 925-926.

2. Ghosh S: Cisplatin: The First Metal Based Anticancer Drug. Bioorganic Chemistry. 2019; 88, 102925.

3. Gozeler MS, Akdemir FNE, Yildirim S, Sahin A, Eser G, and Askin S: Levosimendan ameliorates cisplatin-induced ototoxicity: Rat model. International journal of pediatric otorhinolaryngology. 2019; 122, 70-75.

4. Li Q, Xu L, Ao J, Ai C and Chen X: Identification and bioactivity of a granulocyte colonystimulating factor $b$ homologue from large yellow croaker (Larimichthys crocea). Fish \& Shellfish Immunology. 2019; 90, 20-29.

5. Keiner DD, Kuehn JP, Huber A and Oertel J: Anti-apoptotic impact of granulocyte-colony stimulating factor after peripheral nerve trauma. World Neurosurgery. 2019; 129:e6-e15. 
6. Deshmukh CD, Jain A and Tambe MS: Phytochemical and pharmacological profile of citrullus lanatus (THUNB). Biolife. 2015; 3(2), $483-488$

7. Ademosun $\mathrm{AO}$ and Oboh G: Effect of pineapple, orange and watermelon juices on phosphodiesterase, monoamine oxidase and angiotensin-I converting enzyme activities in rat heart and brain homogenates. Oriental Pharmacy and Experimental Medicine. 2017; 17(3), 269-276.

8. Oyenihi OR, Afolabi BA, Oyenihi AB, Ogunmokun OJ and Oguntibeju OO: Hepatoand neuro-protective effects of watermelon juice on acute ethanol-induced oxidative stress in rats. Toxicology Reports. 2016; 3, 288-294.

9. Owoeye $\mathrm{O}$ and Onwuka SK: Tomato pomace powder ameliorated cisplatin-induced microanatomical alterations in brain of Wistar rats. International Journal of Biological and Chemical Sciences. 2015; 9(1), 1-11.

10. Yung MC, Hsu CC, Kang CY, Lin CL, Chang SL, Wang JJ, Lin MT, Chen PJ and Chen SH: A potential for granulocyte-colony stimulating factor for use as a prophylactic agent for heatstroke in rats. European Journal of Pharmacology. 2011; 661(1-3), 109-117.

11. Ognjanović BI, Djordjević NZ, Matić MM, Obradović JM, Mladenović, JM, Štajn AŠ and Saičić ZS: Lipid peroxidative damage on cisplatin exposure and alterations in antioxidant defense system in rat kidneys: a possible protective effect of selenium. International journal of molecular sciences. 2012; 13(2), 1790-1803.

12. Samarghandian S, Borji A and Farkhondeh $\mathrm{T}$ : Attenuation of oxidative stress and inflammation by Portulaca oleracea in streptozotocin-induced diabetic rats. Journal of Evidence-Based Complementary \& Alternative Medicine. 2017; 22(4), 562-566.

13. Celik I, Seker M and Salbacak A: Histological and histomorphometric studies on the cerebellar cortex and silver stained nucleolus organizer regions of Purkinje neurons in chronic morphine-treated rats. Veterinarski Arhiv. 2018; 88(1), 75-88.

14. Ross M and Pawlina W: Methods. In: Histology, A text and atlas, with correlated cell and molecular biology, 7th ed., Lippincott Williams \& Wilkins, Philadelphia, Baltimore. 2016; pp: 1-2.

15. Suvarna SK, Layton $\mathrm{C}$ and Bancroft JD: Immunohistochemical techniques. In: Bancroft's Theory and Practice of Histological Techniques, 7th ed., Churchill Livingstone Elsevier, London. 2013; pp: 387-418.
16. Suvarna SK, Layton $\mathrm{C}$ and Bancroft JD: Transmission electron microscopy. In: Bancroft's Theory and Practice of Histological Techniques, 7th ed., Elsevier Churchill Livingstone, London. 2013; pp: 493-508.

17. Emsley R, Dunn G and White IR: Mediation and moderation of treatment effects in randomized controlled trials of complex interventions. Statistical Methods in Medical Research. 2010; 19(3), 237-270.

18. Dasari S and Tchounwou PB: Cisplatin in cancer therapy: molecular mechanisms of action. European journal of pharmacology. 2014; 740, 364-378.

19. Albers JW, Chaudhry V, Cavaletti G and Donehower RC: Interventions for preventing neuropathy caused by cisplatin and related compounds. Cochrane Database of Systematic Reviews. 2014; (3).

20. Starobova $\mathrm{H}$ and Vetter I: Pathophysiology of chemotherapy-induced peripheral neuropathy. Frontiers in Molecular Neuroscience. 2017; 10(174), 1-21.

21. Erken HA, Koç ER, Yazııı H, Yay A, Önder GÖ and Sarıcı SF: Selenium partially prevents cisplatin-induced neurotoxicity: a preliminary study. Neurotoxicology. 2014; 42, 71-75.

22. Mao-Ying QL, Kavelaars A, Krukowski K, Huo XJ, Zhou W, Price TJ, Cleeland Ch and Heijnen CJ: The anti-diabetic drug metformin protects against chemotherapy-induced peripheral neuropathy in a mouse model. PLOS ONE. 2014; 9(6), e100701.

23. Karavelioglu E, Boyaci MG, Simsek N, Sonmez MA, Koc R, Karademir M, Guven M and Eser O: Selenium protects cerebral cells by cisplatin induced neurotoxicity. Acta cirurgica brasileira. 2015; 30 (6), 394-400.

24. Turan MI, Cayir A, Cetin N, Suleyman H, Turan IS and Tan H: An investigation of the effect of thiamine pyrophosphate on cisplatin-induced oxidative stress and DNA damage in rat brain tissue compared with thiamine: thiamine and thiamine pyrophosphate effects on cisplatin neurotoxicity. Human \& Experimental Toxicology. 2014; 33(1), 14-21.

25. Akman T, Akman L, Erbas O, Terek MC, Taskiran $\mathrm{D}$ and Ozsaran A: The preventive effect of oxytocin to cisplatin-induced neurotoxicity: an experimental rat model. BioMed Research International. 2015; Article ID 167235.

26. Almutairi MM, Alanazi WA, Alshammari MA, Alotaibi MR, Alhoshani AR, Al-Rejaie SS and Al-Shabanah OA: Neuro-protective effect of rutin 
against Cisplatin-induced neurotoxic rat model. BMC complementary and alternative medicine. 2017; 17(1), 472.

27. Kandeil MA, Mahmoud MO, Abdel-Razik ARH and Gomaa SB: Thymoquinone and geraniol alleviate cisplatin-induced neurotoxicity in rats through downregulating the p38 MAPK/STAT-1 pathway and oxidative stress. Life Sciences. 2019; 228, 145-151.

28. Kamisli S, Ciftci O, Kaya K, Cetin A, Kamisli O and Ozcan C: Hesperidin protects brain and sciatic nerve tissues against cisplatin-induced oxidative, histological and electromyographical side effects in rats. Toxicology and Industrial Health. 2015; 31(9), 841-851.

29. Kaya K, Ciftci O, Cetin A, Tecellioğlu M and Başak N: Beneficial effects of $\beta$-glucan against cisplatin side effects on the nervous system in rats 1. Acta cirurgica brasileira. 2016; 31(3), 198-205.

30. Owoeye O, Awoyemi FO and Ajiboye EO: Ameliorative effects of Raffia hookeri pulp extract on cisplatin-induced brain damage and consequent neurobehavioural changes in Wistar rats. Nigerian Journal of Physiological Sciences. 2018; 33(1), 75-82.

31. Venkataraman P, Selvakumar K, Krishnamoorthy G, Muthusami S, Rameshkumar R, Prakash S and Arunakaran J: Effect of melatonin on PCB (Aroclor 1254) induced neuronal damage and changes in $\mathrm{Cu} / \mathrm{Zn}$ superoxide dismutase and glutathione peroxidase-4 mRNA expression in cerebral cortex, cerebellum and hippocampus of adult rats. Neuroscience research. 2010; 66(2), 189-197.

32. Onaolapo AY, Abdusalam SZ and Onaolapo OJ: Silymarin attenuates aspartame-induced variation in mouse behaviour, cerebrocortical morphology and oxidative stress markers. Pathophysiology. 2017; 24(2), 51-62.

33. Ali EM and Sonpol HM: Neuroprotective and Ameliorating Impacts of Omega-3 against Aspartame-induced Neuronal and Astrocytic Degeneration. The Anatomical Record. 2017; 300(7), 1290-1298.

34. Sancho-Martínez SM, Prieto-García L, Prieto M, López-Novoa JM and López-Hernández FJ: Subcellular targets of cisplatin cytotoxicity: an integrated view. Pharmacology \& Therapeutics. 2012; 136(1), 35-55.

35. Mohamed NA: Chronic effect of aspartame versus stevioside on the cerebellar cortex of the adult albino rat: a histological and immunohistochemical study. Egyptian Journal of Histology. 2013; 36(1): 213-232.
36. El-Dien HMS, El Gamal DA, Mubarak HA and Saleh SM: Effect of fluoride on rat cerebellar cortex: light and electron microscopic studies. The Egyptian Journal of Histology. 2010; 33(2), 245-56.

37. Bekheet SH, Saker SA, Abdel-Kader AM and Younis AEA: Histopathological and biochemical changes of morphine sulphate administration on the cerebellum of albino rats. Tissue and Cell. 2010; 42(3), 165-175.

38. Al-Hayani A, Elshal EB, Aal IHA, Al-Shammeri $\mathrm{E}$ and Kabra $\mathrm{H}$ : Does vitamin $\mathrm{E}$ protect against sodium fluoride toxicity on the cerebellar cortex of albino rats. Middle-East Journal of Scientific Research. 2013; 16(7), 1019-1026.

39. Zhu QF, Zhang CZ and Hua TM: Ethanol induces a reduction in cortical thickness, neuronal density and somatic shrinkage in the cerebellar cortex of adult mice. Neurochemical Journal. 2011; 5(2), 133-137.

40. Wallauer MM, Huf F, Tortorelli LS, Rahmeier FL, Carvalho FB, Meurer RT and da Cruz Fernandes M: Morphological changes in the cerebellum as a result of ethanol treatment and cigarette smoke exposure: A study on astrogliosis, apoptosis and Purkinje cells. Neuroscience letters. 2018; 672, 70-77.

41. Sofroniew MV and Vinters HV: Astrocytes: biology and pathology. Acta Neuropathologica. 2010; 119(1), 7-35.

42. Dossi E, Vasile F and Rouach N: Human astrocytes in the diseased brain. Brain Research Bulletin. 2018; 136, 139-156.

43. Rathinam R, Ghosh S, Neumann WL and Jamesdaniel S: Cisplatin-induced apoptosis in auditory, renal, and neuronal cells is associated with nitration and downregulation of LMO4. Cell Death Discovery. 2015; 1, 15052.

44. Rosic G, Joksimovic J, Selakovic D, Jakovljevic V, Zivkovic V, Srejovic I and Djuric D: The beneficial effects of sulfur-containing amino acids on cisplatininduced cardiotoxicity and neurotoxicity in rodents. Current Medicinal Chemistry. 2018; 25(3), 391-403.

45. Yang Z, Schumaker LM, Egorin MJ, Zuhowski EG, Guo Z and Cullen KJ: Cisplatin preferentially binds mitochondrial DNA and voltage-dependent anion channel protein in the mitochondrial membrane of head and neck squamous cell carcinoma: possible role in apoptosis. Clinical Cancer Research. 2006; 12(19), 5817-5825.

46. Todd RC and Lippard SJ: Inhibition of transcription by platinum antitumor compounds. Metallomics. 2009; 1(4), 280-291. 
47. Afifi OK: Effect of sodium fluoride on the cerebellar cortex of adult albino rats and the possible protective role of vitamin B6: A light and electron microscopic study. Egyptian Journal of Histology. 2009; 32(2), 358-367.

48. Abou-Elghait A, El-Gamal DA, Abdel-Sameea AR and Mohamed AA: Effect of cisplatin on the cerebellar cortex and spinal cord of adult male albino rat and the possible role of vitamin E: light and electron microscopic study. Egyptian Journal of Histology. 2010; 33(2), 202-212.

49. Lomeli N, Di K, Czerniawski J, Guzowski JF and Bota DA: Cisplatin-induced mitochondrial dysfunction is associated with impaired cognitive function in rats. Free Radical Biology and Medicine. 2017; 102, 274-286.

50. Maj MA, Ma J, Krukowski KN, Kavelaars A and Heijnen CJ: Inhibition of mitochondrial p53 accumulation by PFT- $\mu$ prevents cisplatin-induced peripheral neuropathy. Frontiers in Molecular Neuroscience. 2017; 10(108), 1-13.

51. Saxena M, Delgado Y, Sharma RK, Sharma S, Guzmán SL, Tinoco AD and Griebenow K: Inducing cell death in vitro in cancer cells by targeted delivery of cytochrome c via a transferrin conjugate. PLOS ONE. 2018; 13(4), e0195542.

52. Mohamed HK and Mohamed HZ: A histological and immunohistochemical study on the possible protective role of silymarin on cerebellar cortex neurotoxicity of lactating albino rats and their pups induced by gibberellic acid during late pregnancy and early postnatal period, Egyptian Journal of Histology. 2018; 41(3), 345-371.

53. Al Moundhri MS, Al-Salam S, Al Mahrouqee A, Beegam S and Ali BH: The effect of curcumin on oxaliplatin and cisplatin neurotoxicity in rats: some behavioral, biochemical, and histopathological studies. Journal of Medical Toxicology. 2013; 9(1), 25-33.

54. McFadden SL and Salvi RJ: Calpain immunoreactivity and morphological damage in chinchilla inner ears after carboplatin. Journal of the Association for Research in Otolaryngology. 2002; 3(1), 68-79.

55. Özdemir NG, Akbas F, Kotil TU and Yılmaz A: Analysis of diabetes related cerebellar changes in streptozotocin-induced diabetic rats. Turkish Journal of Medical Sciences. 2016; 46(5), 1579-1592.

56. Liska MG and dela Peña I: Granulocyte-colony stimulating factor and umbilical cord blood cell transplantation: Synergistic therapies for the treatment of traumatic brain injury. Brain Circulation. 2017; 3(3), 143-151.
57. Iwasaki M, Adachi Y, Minamino K, Suzuki Y, Zhang Y, Okigaki M and Taketani S: Mobilization of bone marrow cells by G-CSF rescues mice from cisplatin-induced renal failure, and M-CSF enhances the effects of G-CSF. Journal of the American Society of Nephrology. 2005; 16(3), 658-666.

58. Ghorbani M, Mohammadpour AH, Abnous K, Movassaghi AR, Sarshoori JR, Shahsavand $\mathrm{S}$ and Moallem SA: G-CSF administration attenuates brain injury in rats following carbon monoxide poisoning via different mechanisms. Environmental Toxicology. 2017; 32(1), 37-47.

59. Thummasorn S, Kumfu S, Chattipakorn S and Chattipakorn N: Granulocyte-colony stimulating factor attenuates mitochondrial dysfunction induced by oxidative stress in cardiac mitochondria. Mitochondrion. 2011; 11(3), 457-466.

60. Chang YC, Lin CY, Hsu CM, Lin HC, Chen YH, Lee-Chen GJ and Hsieh-Li HM: Neuroprotective effects of granulocyte-colony stimulating factor in a novel transgenic mouse model of SCA17. Journal of neurochemistry. 2011; 118(2), 288-303.

61. Schneider A, Krüger C, Steigleder T, Weber D, Pitzer C, Laage $\mathrm{R}$ and Hasselblatt $\mathrm{M}$ : The hematopoietic factor G-CSF is a neuronal ligand that counteracts programmed cell death and drives neurogenesis. The Journal of Clinical Investigation. 2005; 115(8), 2083-2098.

62. Nishio Y, Koda M, Kamada T, Someya Y, Kadota R, Mannoji C and Yamazaki M: Granulocyte colony-stimulating factor attenuates neuronal death and promotes functional recovery after spinal cord injury in mice. Journal of Neuropathology \& Experimental Neurology. 2007; 66(8), 724-731.

63. Adusumilli A, Rao KR and Krothapalli SR: The clinical applications of Hematopoietic growth factor-GCSF. Asian Journal of Biomedical and Pharmaceutical Sciences. 2012; 2(14), 1-10.

64. Dittgen T, Pitzer C, Plaas C, Kirsch F, Vogt G, Laage $\mathrm{R}$ and Schneider A: Granulocyte-colony stimulating factor (G-CSF) improves motor recovery in the rat impactor model for spinal cord injury. PLOS ONE. 2012; 7(1), e29880.

65. Morita Y, Takizawa S, Kamiguchi H, Uesugi T, Kawada $\mathrm{H}$ and Takagi S: Administration of hematopoietic cytokines increases the expression of anti-inflammatory cytokine (IL-10) mRNA in the subacute phase after stroke. Neuroscience Research. 2007; 58(4), 356-360.

66. Toth ZE, Leker RR, Shahar T, Pastorino S, Szalayova I, Asemenew B and Bratincsák A: The combination of granulocyte colony-stimulating factor and stem cell factor significantly increases 
the number of bone marrow-derived endothelial cells in brains of mice following cerebral ischemia. Blood. 2008; 111(12), 5544-5552.

67. Marzban M, Bakhtiary M, Mehdizadeh M, Taghi Joghataei M, Khoei S, Pirhajati Mahabadi V and Ebrahimi A: Mobilization of stem cell with granulocyte-colony stimulating factor promotes recovery after traumatic brain injury in rat. Basic and Clinical Neuroscience. 2010; 1(2), 37-42.

68. Mohammad MKA, Mohamed MI, Zakaria AM, Abdul Razak HR and Saad WMM: Watermelon (Citrullus lanatus (Thunb.) Matsum. and Nakai) juice modulates oxidative damage induced by low dose X-ray in mice. BioMed research international. 2014; Article ID 512834.

69. Asita AO and Molise $\mathrm{T}$ : Antimutagenic effects of red apple and watermelon juices on cyclophosphamide-induced genotoxicity in mice. African Journal of Biotechnology. 2011; 10(77), 17763-17768.

70. Naz A, Butt MS, Sultan MT, Qayyum MMN and Niaz RS: Watermelon lycopene and allied health claims. EXCLI Journal. 2014; 13, 650-666.

71. Costa-Rodrigues J, Pinho O and Monteiro PRR: Can lycopene be considered an effective protection against cardiovascular disease?. Food Chemistry. 2018; 245, 1148-1153.

72. Campos KKD, Araújo GR, Martins TL, Bandeira ACB, de Paula Costa G, Talvani A and Bezerra FS: The antioxidant and anti-inflammatory properties of lycopene in mice lungs exposed to cigarette smoke. The Journal of Nutritional Biochemistry. 2017; 48, 9-20.

73. Sahin K, Tuzcu M, Sahin N, Ali S and Kucuk O: Nrf2/HO-1 signaling pathway may be the prime target for chemoprevention of cisplatin-induced nephrotoxicity by lycopene. Food and Chemical Toxicology. 2010; 48(10), 2670-2674.

74. Teixeira WGJ, Cristante AF, Marcon RM, Bispo G, Ferreira R and de Barros-Filho TEP: Granulocyte Colony-Stimulating Factor Combined with Methylprednisolone Improves Functional Outcomes in Rats with Experimental Acute Spinal Cord Injury. Clinics. 2018; 73:e235.

75. Mogotlane EA, Mokwala PW and Mangena P Comparative analysis of the chemical compositions of indigenous watermelon (Citrullus lanatus) seeds from two districts in Limpopo Province, South Africa. African Journal of Biotechnology. 2018; 17(32), 1001-1006. 
الملخص العربى

تأثير السيسبلاتين على قثرة مخيخ الجرذ الأبيض والدور الوقائي المحتمل للعامل المحفز

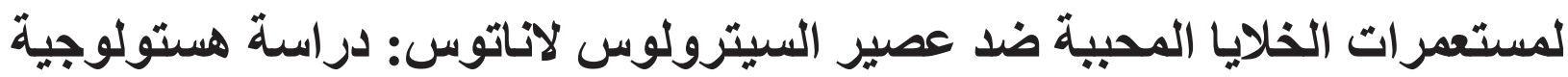

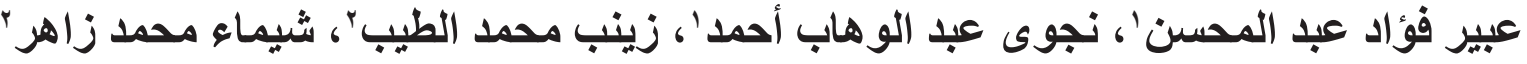

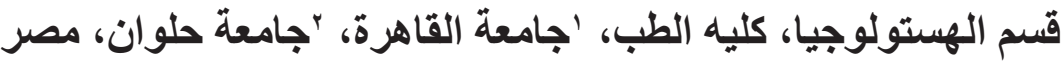

الخلفية: السيسبلاتين له تأثنير مضاد للأور ام ضد مجمو عة واسعة من الأور ام الصلبة. ومع ذلك، فإن استخدامه السريري محدود بسبب آثاره الضارة، وخاصة على الجهاز العصبين لتصني. الهدف من العمل: تقييم تأثير السيسبلاتين على التركيب النسيجي لقشرة المخيخ و الدور الوقائي المحتمل للعامل المحفز لمستعمر ات الخلايا المحببة مقابل عصير السيترولوس لاناتيرس (البطيخ). المواد والطرق: تم تقسيم أربعين من ذكور الجرذان البيضاء البالغة إلى المجموعة الضابطة، المجموعة الأولى: تلقت

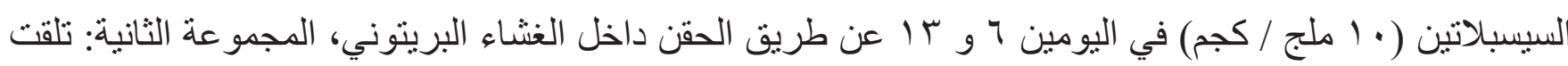

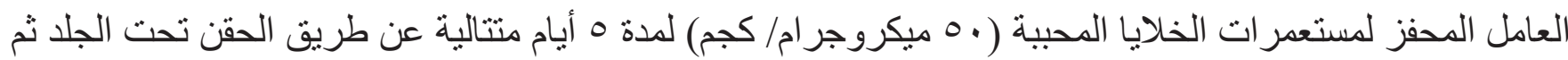
تلقت السيسبلاتين كما في المجموعة الأولى والمجموعة الثالثة: تلقت السيسبلاتين كما في المجموعة الأولى وألى وأيضا عصير السيترولوس لاناتوس (عمل/كجم) يوميًا لمدة 17 يومًا عن طريق الفم. تم أخذ عينات من الدم لقياس إنزيمي

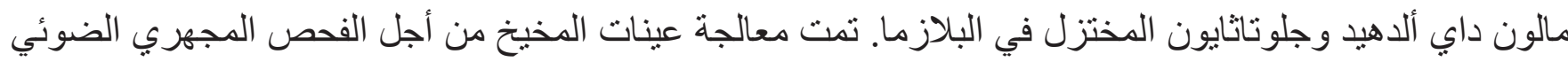

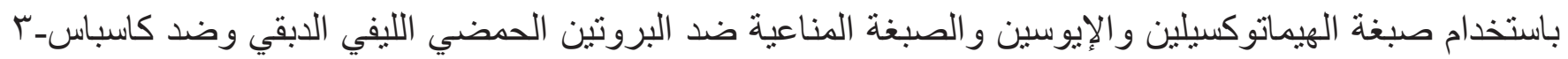
و أيضا من أجل الفحص المجهري الإكتروني. وقد أجريت القياسات الثكلية والإحصائية حيث تم قياس عدد خلايا بركينجي، سمك الطبقة الحبييية، النسبة المئوية لمساحة الخلايا النجمية الإيجابية للبروتين الحمضي الليفي الدبقي

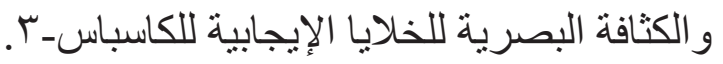
النتائج: أظهرت المجموعة الأولى زيادة ملحوظة في مستوى البلازما لإنزيم مالون داي ألدهيد و انخفاضاً في مستوى

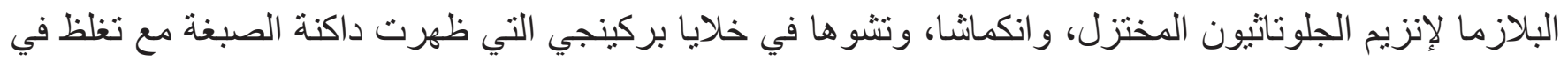
الأنوية، وتورم الميتوكوندريا مع أعر اف مدمرة وحويصلات متسعة لجهاز جولجي. كما كانت الخلايا الحبييية المنفصلة عن بعضها منكمشة مع أنوية غير منتظمة وداكنة. تم تأكيد النتائج من خلال القياسات الثكلية و الإحصائية. وقد تحسنت التغيير ات في المجمو عتين الثانية و الثالثة ولكن إلى حد كبير في المجمو عة الثانية مقارنة بالمجمو عة الثالثة. الخلاصة: يمكن للعامل المحفز لمستعمر ات الخلايا المحبية أن يحسن التغيرات التي يسببها السيسبلاتين في قشرة المخيخ بشكل أفضل من عصبر السيترولوس لاناتوس. 